\title{
Mycorrhizal status of selected herbaceous plants in Molinia meadows of Folusz, near Szubin (Poland)
}

\author{
Natalia Stokłosa $^{1 *}$, Ewa Krasicka-Korczyńska ${ }^{2}$, Barbara Kieliszewska-Rokicka1 \\ ${ }^{1}$ Kazimierz Wielki University, Faculty of Natural Sciences, Department of Mycology and Mycorrhiza, \\ Ossolińskich 12, 85-093 Bydgoszcz, Poland, *e-mail: n.stoklosa@ukw.edu.pl \\ ${ }^{2}$ University of Science and Technology in Bydgoszcz, Faculty of Agriculture and Biotechnology, \\ Department of Botany and Ecology, Kaliskiego 7, 85-796 Bydgoszcz, Poland
}

\begin{abstract}
This preliminary study examined the arbuscular mycorrhizal (AM) status of native plant species in the Molinia meadows of Folusz in the Kujawy region, Poland. Root samples from ten plant species characteristic of Molinia meadows (Betonica officinalis, Dianthus superbus, Galium boreale, Inula salicina, Ostericum palustre, Sanguisorba officinalis, Selinum carvifolia, Serratula tinctoria, Silaum silaus, and Succisa pratensis) were collected in August 2014. Root colonization by AM fungi was considered an indicator of symbiosis development. AM was found in all plant species examined. The frequency of mycorrhizal structures ranged between $68 \%$ and $99 \%$. The intensity of mycorrhizal colonization in roots varied with the plant species, ranging between $3.9 \%$ (O. palustre) and $40.1 \%$ (B. officinalis). To our knowledge, this is the first study to examine the mycorrhizal status of three species: $D$. superbus, $O$. palustre, $S$. carvifolia. Because AM colonization depends on plant genotype and environmental factors, further studies should examine seasonal variability in plant root colonization and the compositions of AM fungal communities, which may serve as indicators of site conditions.
\end{abstract}

Key words: arbuscular mycorrhiza, Glomeromycota, mycorrhizal colonization, Natura 2000 site, soil.

\section{Introduction}

Molinia meadows comprise a valuable, semi-natural grassland ecosystem. They are covered by a mixture of grasses, herbaceous plants, and other low-growing plant species. Molinia meadows are created and maintained by people that practice a specific type of low-intensity, traditional farming that includes grazing, mowing at least once a year, and no fertilization (Kącki \& Załuski 2004; MichalskaHejduk \& Kopeć 2012). Cessation of farming practices can induce ecosystem transformations into herbaceous fields, scrubland, forests, or sedge rushes (Michalska-Hejduk \& Kopeć 2012). In the European Union, this meadow region is protected by law (Habitat Directive), because it provides habitats for many rare and protected plants and birds (Kącki \& Załuski 2004; Matuszkiewicz 2005; Michalska-Hejduk \& Kopeć 2012; Kulik 2013).
Under natural conditions, $80 \%$ of all vascular plant species develop mycorrhizas, which are mutual symbiotic associations between plant roots and fungi specialized for growth in soils and plants. Mycorrhizas improve plant nutrition and water balance, increase plant growth, promote the establishment of plants in new areas, and play an important role in plant functions and in the function of entire ecosystems (Brundrett 2004; Smith \& Read 2008). Arbuscular mycorrhizas (AMs) are produced by Glomeromycota fungi in roots of a wide range of plant species, particularly herbaceous plants and grasses. Arbuscular mycorrhizal fungi (AMF) also improve soil conservation by contributing to the soil aggregation process, controlling soil erosion, and maintaining nutrient reserves (Miller \& Jastrov 1992).

$\mathrm{AM}$ is the most common mycorrhizal association in the world; it is widespread in all types of environments (Trappe 1987; Allen 1991). Also, AMF are the main components of 
soil microbiota (Smith \& Read 2008). Nevertheless, only about $3 \%$ of known plant species have been examined to study associated mycorrhizal fungi (Trappe 1987; Wang \& Qiu 2006). Little is known about AMF colonizations in plants in Molinia meadows and the relationships between site conditions, plant development, and mycorrhiza. Only a few studies have focused on the AM status of plants characteristic of this type of habitat, including Harley \& Harley (1987a, b; 1990), Eriksen et al. (2002), Fuchs \& Haselwandter (2004), and Wang \& Qiu (2006).

Environmental factors, such as land use changes, soil fertilization, or contamination with xenobiotic substances, can affect the functions of above-ground and below-ground biota. Thus, mycorrhizal status might serve as an indicator of environmental changes. This study aimed to examine the presence of mycorrhizal symbiosis and to assess the frequency and abundance of mycorrhizal fungi in roots of ten selected herbaceous plant species, characteristic of Molinia meadows. These plants represented seven families (Table 1). The results broadened our knowledge of the ecology of this valuable, semi-natural grassland ecosystem.

\section{Study area}

This study was conducted in Molinia meadows (subtype Selino carvifoliae-Molinietum) located in Folusz (17\%49' E, 52 $47^{\prime} \mathrm{N}$ ), near Szubin, in Gąsawka Valley (Gąsawka River - left tributary of Noteć River), ca. $30 \mathrm{~km}$ southwest of Bydgoszcz city (Kuyavian-Pomeranian Province). The study area was about 50 ha (Krasicka-Korczyńska \& Rutkowski 2005), which formed part of the Szubin-Łabiszyn Plain Microregion (315.353), located in the Mesoregion, Torun Basin (Kondracki 2000). According to Matuszkiewicz (2008), Folusz belongs to the Szubin Subdistrict, which is part of the Chodziez District. The Molinia meadows are surrounded on the south and east by moraine hills. The central part of this area includes a complex of fishing ponds; the northwestern area harbors numerous post-excavation peat pits. The Molinia meadows are composed of muck soils. Selected soil properties are shown in Table 2. The meadows are mowed, usually twice a year. The $\mathrm{Mo}$ linia meadows community was classified as Selino-Molinietum brometosum erecti (Matuszkiewicz 2005). This community represents a typical Molinia meadow, with many characteristic species, including Betonica officinalis, Dianthus superbus, Galium boreale, Inula salicina, Molinia caerulea, Ostericum palustre, Selinum carvifolia, Succisa pratensis, Serratula tinctoria, Gentiana pneumonanthe, Laserpitium prutenicum, Silaum silaus. This area harbors 27 endangered or protected plant species (Krasicka-Korczyńska \& Rutkowski 2005). In 2010, this area was classified as a Natura 2000 site, called "Molinia meadows in Folusz" (code PLH040027).

\section{Materials and methods}

Among the plant species typical of Molinia meadows (Matuszkiewicz 2005; Michalska-Hajduk \& Kopeć 2012), we selected the ten most frequently observed species at the study site for AM evaluation. We employed the nomenclature of plant species described by Mirek et al. (2002), the phytocenotic character of species, and the names of plant communities described by Matuszkiewicz (2005).

We collected random specimens of the following herbaceous plants: Betonica officinalis, Dianthus superbus, Galium boreale, Inula salicina, Ostericum palustre, Sanguisorba officinalis, Selinum carvifolia, Serratula tinctoria, Silaum silaus and Succisa pratensis. Triplicate samples of each plant were collected with a spade in August 2014. Root systems were cut off, placed in plastic bags, and transported to the laboratory. Fungal structures in roots were visualized according to the method described by Kormanik and McGraw (1982), with modifications. Briefly, fresh fine roots (about $0.1 \mathrm{~g}$ ) were cut into $1-\mathrm{cm}$ segments, cleared for $20 \mathrm{~min}$ in $10 \% \mathrm{KOH}$, and stained in $0.05 \%$ trypan blue solution for $8 \mathrm{~min}$. The entire procedure was carried out at $90^{\circ} \mathrm{C}$ in a water bath. The stained roots were stored in lactoglycerol. The mycorrhizal colonization in each root system was estimated with the method described by Trouvelot et al. (1986). Thirty root segments $(30 \mathrm{~cm})$ from each sample were examined with a light microscope under 100x magnification (Zeiss Axiostar Plus). We recorded the frequency of mycorrhiza in the root system $(\mathrm{F} \%)$, the intensity of the mycorrhizal colonization in the root system $(\mathrm{M} \%)$, and the arbuscule abundance in the root system (A\%). Mycorrhizal colonization was quantified with the software program, 'Mycocalc' (http://www2. dijon.inra.fr). Soil analyses were performed in the laboratory of the Department of Agricultural Chemistry of the University of Science and Technology, in Bydgoszcz.

\section{Results}

The ten plant species selected for AM evaluation at the Molinia meadows in Folusz near Szubin represented 10 plant genera and 7 families (Table 1). All plants investigated were colonized by AM fungi. The presence of arbuscules, vesicles, hyphal coils, and intraradical hyphae were observed in roots of all plant species, with the exception of G. boreale, S. silaus, and S. pratensis, which had roots without hyphal coils (Fig. 1). The degree of AM colonization varied among plant species (Fig. 2). B. officinalis (Lamiaceae) had the highest and $O$. palustre (Apiaceae) had the lowest AM parameter values ( $\mathrm{F} \%, \mathrm{M} \%$, and $\mathrm{A} \%$ ). The average AM frequency ( $\mathrm{F} \%$ ) was relatively high in all the plant species investigated; it ranged from $62.2 \%$ (O. palustre) to $98.9 \%$ (B. officinalis). The mycorrhizal 
Table 1. Characteristics of growth and flowering period of plant species investigated in this study (Rutkowski 2007)

\begin{tabular}{|l|c|c|c|}
\hline \multirow{2}{*}{ Family } & Plant species & $\begin{array}{c}\text { Height } \\
{[\mathrm{cm}]}\end{array}$ & $\begin{array}{c}\text { Flowering } \\
\text { period }\end{array}$ \\
\hline \multirow{3}{*}{ Apiaceae } & Ostericum palustre Besser & $50-125$ & VI-IX \\
\cline { 2 - 4 } & Selinum carvifolia (L.) L. & $30-100$ & VII-IX \\
\cline { 2 - 4 } & Silaum silaus (L.) Sch. et Thell. & $50-100$ & VI-IX \\
\hline \multirow{2}{*}{ Asteraceae } & Inula salicina L. & $30-60$ & VI-VIII \\
\cline { 2 - 4 } & Serratula tinctoria L. & $30-100$ & VII-IX \\
\hline Caryophyllaceae & Dianthus superbus L. & $20-50$ & VI-IX \\
\hline Dipsacaceae & Succisa pratensis Moench & $15-80$ & VII-IX \\
\hline Lamiaceae & Betonica officinalis L. & $30-75$ & VI-IX \\
\hline Rosaceae & Sanguisorba officinalis L. & $30-90$ & VI-IX \\
\hline Rubiaceae & Galium boreale L. & $20-60$ & V-VIII \\
\hline
\end{tabular}

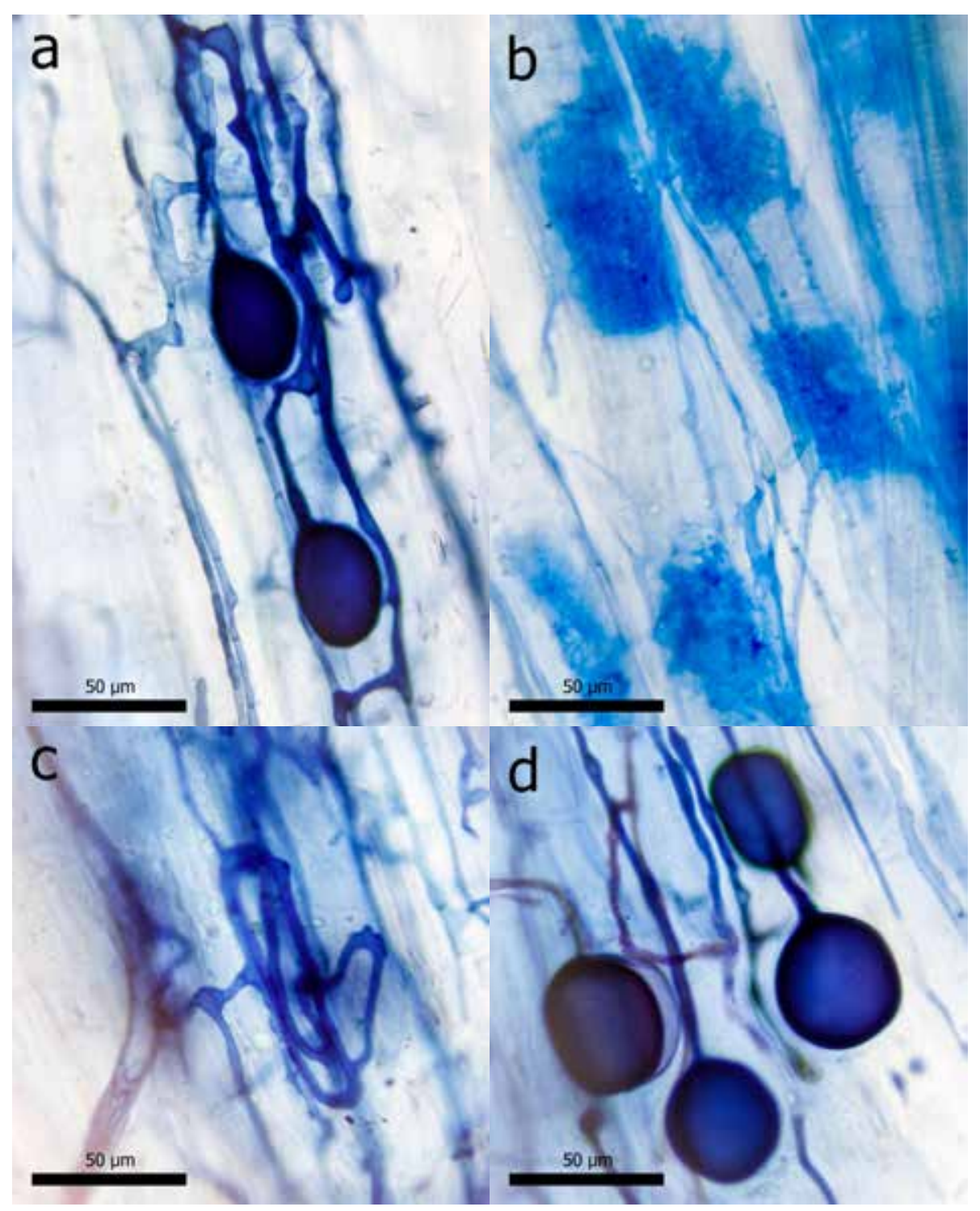

Figure 1. Arbuscular mycorrhiza in plant roots: (a) vesicles and intraradical hyphae within a root of Ostericum palustre; (b) arbuscules and intraradical hyphae within cortical cells of a root of Selinum carvifolia; (c) hyphal coil within a root of Dianthus superbus; (d) vesicles and intraradical hyphae within a root of D. superbus 


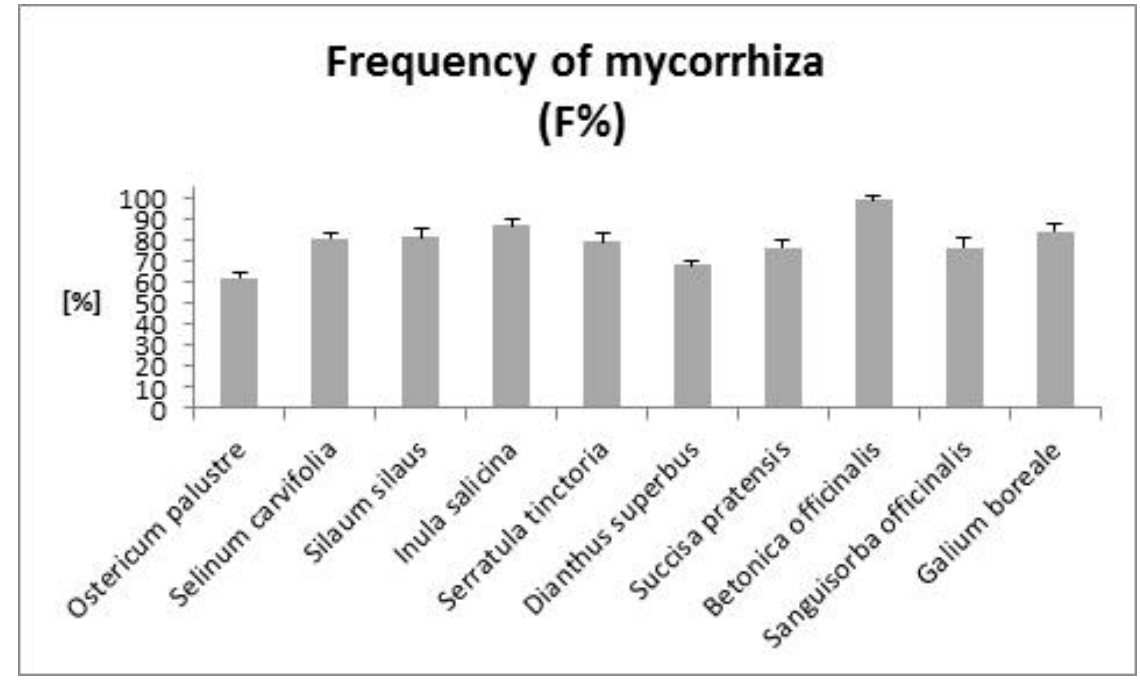

\section{Intensity of the mycorrhizal colonisation}

(M\%)

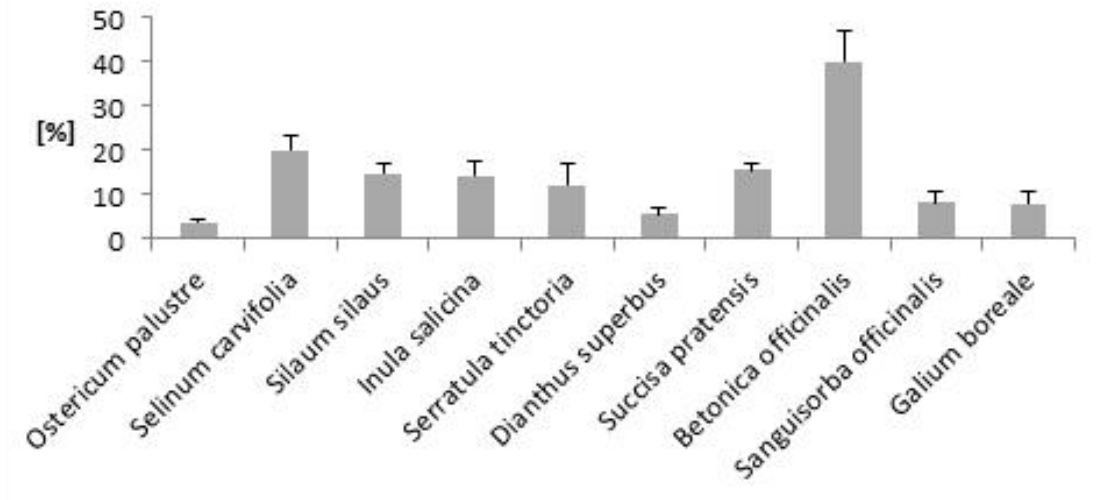

\section{Arbuscule abundance}

(A\%)

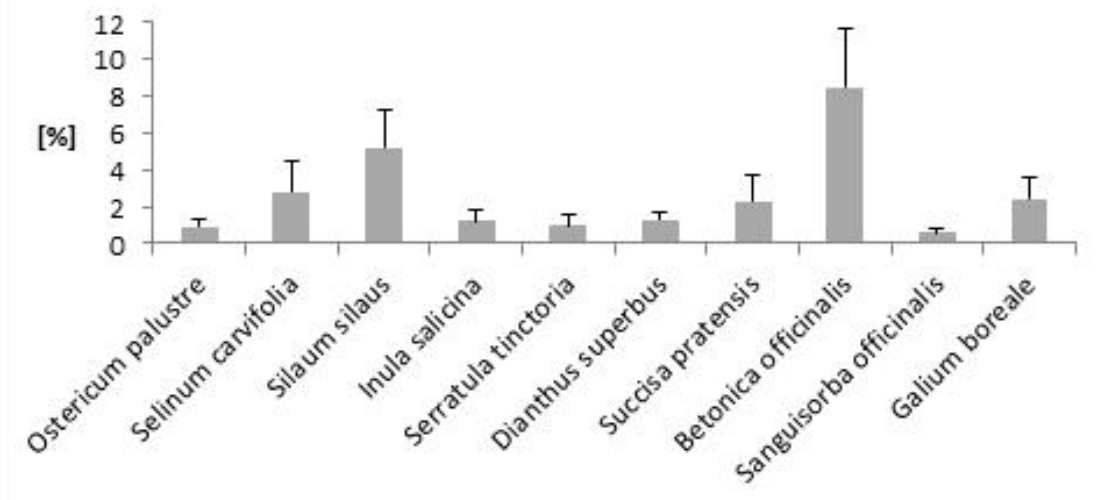

Figure 2. Mycorrhizal colonization of selected herbaceous plants characteristic of Molinia meadows, located in Folusz, near Szubin. (a) Frequency of mycorrhiza in the root system (F\%); (b) intensity of mycorrhizal colonization in the root system (M\%); (c) arbuscule abundance in the root system (A\%). Data are means $(n=3)$; bars indicate standard deviations 
frequency was lower than $70 \%$ in only two plant species (D. superbus and $O$. palustre) (Fig. 2a). The intensity of mycorrhizal colonization in the root systems (M\%) varied between $3.9 \%$ (O. palustre) and 40.1\% (B. officinalis) (Fig. $2 \mathrm{~b})$. Arbuscule abundance in the root systems (A\%) was relatively low; it comprised between $0.6 \%$ (S. officinalis) and $8.5 \%$ (B. officinalis) of the root systems (Fig. 2c).

\section{Discussion}

Although AM is the predominant type of mycorrhiza in land plants, AM colonization has been confirmed in only about $3 \%$ of plant species. The first list of mycorrhizal status in vascular plants included 1,101 species and 144 families of plants in British flora (Harley \& Harley 1987a, b; 1990). Nineteen years later, Wang \& Qiu (2006) developed a list of mycorrhizas in land plants, based on 659 papers, including those by Harley \& Harley (1987a, b; 1990). That list comprised 3,617 species (angiosperms, gymnosperms, pteridophytes, and bryophytes), which belonged to 263 families.

Our research confirmed the AM status of seven species that were previously described by other authors as AM plants: $G$. boreale, I. salicina, $S$. silaus, $S$. officinalis (Harley \& Harley 1987a, b; 1990), B. officinalis (Fuchs \& Haselwandter 2004), S. tinctoria (Harley \& Harley 1987a, b; 1990; Fuchs \& Haselwandter 2004), and S. pratensis (Harley \& Harley 1987a, b; 1990; Eriksen et al. 2002). To our knowledge, this study was the first to describe the mycorrhizal status of three plant species: D. superbus, $O$. palustre, and $S$. carvifolia. One of the species, $D$. superbus, belongs to the family Caryophyllaceae, previously considered 'nonmycorrhizal', because they comprise relatively large numbers of non-host plant species, which can adversely influence mycorrhizal fungi (Brundrett 2009). In our study, roots of $D$. superbus contained low levels of AM colonizations (M\% 5.7, A\% 1.3; Fig. 2); however, these levels were comparable to those observed in other plants that co-existed in the Molinia meadows of Folusz, such as $O$. palustre (Asteraceae), G. boreale (Rubiaceae), and S. officinalis (Rosaceae; Fig. 2). In the literature, reports have been contradictory concerning the mycorrhizal status of species that belong to the genus Dianthus. For example, D. caryophyllus, D. gratianopolitanus, and D. plumarius were listed as nonmycorrhizal plants (Harley \& Harley 1987a, b, 1990; St-Arnaud et al. 1997; Zubek et al. 2008); however, D. caryophyllus was reported to develop AM associations with a variety of AM fungi in greenhouse conditions (Kerur \& Lakshman 2009). According to Harley \& Harley (1987a, b, 1990), D. deltoides is nonmycorrhizal. However, Lekberg et al. (2015) found low AM colonization in the roots of this plant grown in Danish coastal grasslands. Similarly, Pawłowska et al. (1996) and Gucwa-Prze- pióra \& Błaszkowski (2007) reported the presence of AM structures in the roots of $D$. carthusianorum, a species listed as nonmycorrhizal by Harley and Harley (1987a, b, 1990). Moreover, Gucwa-Przepióra \& Błaszkowski (2007) found relatively high AM parameter values $(\mathrm{F} \%=80.0$; $\mathrm{M} \%=45.5 ; \mathrm{A} \%=23.2)$ in roots of this plant species. It is noteworthy that many plant families and genera can contain both mycorrhizal and nonmycorrhizal species (Wang \& Qiu 2006). Some authors suggested that, in some cases, AM structures may be present in plant roots, but they are not observed, because they do not react with commonly used dyes (Morton \& Redecker 2001; Kowalczyk \& Błaszkowski 2005). Lekberg et al. (2015) examined AM fungi in the roots of $D$. deltoides with microscopy, signature fatty acid (NLFA 16:165) analysis, and molecular identification. They demonstrated that this species exhibited substantially lower AM colonization than that observed in neighboring plants. The authors suggested that some non-host plants may be colonized by AM fungi, when grown together with host plants. According to Lekberg et al. (2015), the distinction between host and nonhost plants is very subtle, and more research is needed to improve our understanding of plant-AM fungal interactions.

This study revealed significant differences in mycorrhizal frequency $(\mathrm{F} \%)$, the intensity of colonization $(\mathrm{M} \%)$, and the abundance of arbuscules in plant roots $(\mathrm{A} \%)$ among the ten plant species examined (Fig. 2). However, these plants were collected only once, in August. Moreover, the levels of AM colonization observed in the plants examined in this study were lower than the levels observed in other studies. For example, in the roots of S. officinalis grown in Folusz, the parameters were: F\% 81.3, M\% 8.3, and $\mathrm{A} \% 0.6$ (Fig. 2). However, roots of the same species, grown in the Botanical Garden of Jagiellonian University in Kraków, and collected in June, showed parameters of: F\% 91.3, M\% 36.3, and A\% 18.4 (Zubek et al. 2011).

The degree of mycorrhizal colonization can be determined by many factors, including the availability of nutrients and water in soil, the season, the density of inoculum, the vegetation development, and the genotypes of phytobionts and mycobionts (Friese \& Allen 1991; Smith \& Read 2008). According to several published papers, the colonization of plant roots by AM is variable throughout the year; it is associated with host phenology and climatic variations. Therefore, each plant species may have different seasonal patterns (Allen 1996; Garcia \& Mendoza 2008; Lingfei et al. 2005). However, some studies have indicated that mycorrhizal colonization is more closely related to plant physiology than to phenology.

Arbuscules, the major sites of nutrient exchange between the fungus and host, are ephemeral structures, often absent in field-collected roots (Brundrett 2004). However, it has been reported that arbuscules are more abundant at the beginning of the growing season, during periods of ac- 
Table 2. Selected properties of the soil in Molinia meadows in Folusz

\begin{tabular}{|l|c|}
\hline Variables & Values \\
\hline $\mathrm{pH}\left(\mathrm{H}_{2} \mathrm{O}\right)$ & 6.55 \\
$\mathrm{pH}(\mathrm{KCl})$ & 6.38 \\
$\mathrm{~N}$ total $\left[\mathrm{g} \mathrm{kg}^{-1}\right.$ air d.w.] & 10.37 \\
$\mathrm{C}$ organic $\left[\mathrm{g} \mathrm{kg}^{-1}\right.$ air d.w.] & 154.80 \\
$\mathrm{P}$ available $\left[\mathrm{mg} \mathrm{kg}^{-1}\right.$ air d.w.] & 26.20 \\
$\mathrm{~K}$ available $\left[\mathrm{mg} \mathrm{kg}^{-1}\right.$ air d.w.] & 14.00 \\
\hline
\end{tabular}

tive nutrient uptake (Allen 1983, Garcia \& Mendoza 2008; Sawilska et al. 2010). Several authors observed increasing arbuscular abundance between spring and mid-summer and decreasing abundance from mid-summer to late autumn (Sawilska et al. 2010; Tyburska et al. 2013). Therefore, in the present study, the sampling date (August) may have influenced our findings of low arbuscule abundance in all the plants examined $(\mathrm{A} \%=0.6-8.5)$. Furthermore, several factors, like soil moisture, aeration, and temperature, might also influence arbuscule development (Khan 1995).

It is known that AM symbiosis improves phosphorus and nitrogen uptake under limiting conditions. However, high availability of exogenous phosphate and nitrate was shown to inhibit root colonization by the AM fungus, Rhizophagus irregularis (Nouri et al. 2014). That observation suggested that a feedback mechanism may cause plants to promote or limit AM colonization, according to nutrient needs. Our finding that the roots of plants from the Molinia meadows in Folusz had relatively low mycorrhizal AM colonization may have been linked to the relatively high $\mathrm{N}, \mathrm{C}$, and $\mathrm{P}$ concentrations in the soil (Table 2). Conversely, the average AM colonization was elevated in herbaceous plants grown at a soda-contaminated site; this might be linked to the relatively low concentration of available essential nutrients in the soil (Gucwa-Przepióra \& Błaszkowski 2007).

In this study, the water status may have had an impact on the degree of mycorrhizal colonization in plant roots. Molinia meadows are characterized by variable levels of ground water. Ground water can be very high at the beginning of the growing season, and the meadows may be flooded. However, at the end of summer, groundwater is often very low, out of reach for the root systems of many plants (Michalska-Hejduk \& Kopeć 2012).

To date, the "Molinia meadows in Folusz", Nature 2000 site (PLH040027), has mainly been investigated to examine floristic and phytosociological aspects (KrasickaKorczyńska \& Rutkowski 2005; Nienartowicz et al. 2014). The present study provided basic information on the mycorrhizal status of selected plant species characteristic of Molinia meadows. However, further research is needed to determine the seasonality of mycorrhizal colonization and the composition of the associated AM fungal community.
That information might facilitate the design of future conservation and restoration programs that target semi-natural Molinia meadows.

\section{Acknowledgements}

This research was financially supported by the Kazimierz Wielki University (statutory project).

\section{References}

Allen M.F., 1983, Formation of vesicular-arbuscular mycorrhizae in Atriplex gardneri (Chenopodiaceae): seasonal response in a cold desert, Mycologia 75: 773-776.

Allen M.F., 1991, The ecology of mycorrhizae, University Press, Cambridge.

Allen M.F., 1996, The ecology of arbuscular mycorrhizas: a look back into the 20th century and a peek into the 21st, Mycological Research 100(7): 769-782.

Brundrett M., 2004, Diversity and classification of mycorrhizal associations, Biological Reviews 79: 473-495.

Brundrett M., 2009, Mycorrhizal associations and other means of nutrition of vascular plants: understanding the global diversity of host plants by resolving conflicting information and developing reliable means of diagnosis, Plant and Soil 320: 37-77.

Eriksen M., Bjureke K.E. \& Dhillion S.S., 2002, Mycorrhizal plants of traditionally managed boreal grasslands in Norway, Mycorrhiza 12: 117-123.

Friese C.F. \& Allen M.F., 1991, The spread of VA mycorrhizal fungal hyphae in the soil: inoculum types and external hyphal architecture, Mycologia 83: 409-418.

Fuchs B. \& Haselwandter K., 2004, Red list plants: colonization by arbuscular mycorrhizal fungi and dark septate endophytes, Mycorrhiza 14: 277-281.

Garcia I.V. \& Mendoza R.E., 2008, Relationships among soil properties, plant nutrition and arbuscular mycorrhizal fungi-plant symbioses in a temperate grassland along hydrologic, saline and sodic gradients, FEMS Microbiology Ecology 63: 359-371.

Gucwa-Przepióra \& Błaszkowski J., 2007, Arbuscular mycorrhiza of plants spontaneously colonizing the soda heap in Jaworzno (Southern Poland), Acta Societatis Botanicorum Poloniae 76 (1): 69-74.

Harley J.L. \& Harley E.L., 1987a, A check-list of mycorrhiza in the British Flora, New Phytologist 105: 1-102.

Harley J.L. \& Harley E.L.,1987b, A check-list of mycorrhiza in the British Flora - addenda, errata and index, New Phytologist 107: 741-749.

Harley J.L. \& Harley E.L., 1990, A check-list of mycorrhiza in the British Flora - second addenda and errata, New Phytologist 115: 699-711. 
Kącki Z. \& Załuski T., 2004, Zmiennowilgotne łąki trzęślicowe (Molinion) [Molinia meadows (Molinion) with varying moisture conditions], [in:] J. Herbich (ed.), Murawy, łąki, ziołorośla, wrzosowiska, zarośla. Poradnik ochrony siedlisk i gatunków Natura 2000 [Grasslands, meadows, tall herb vegetation, heaths, thickets. Guide book to Natura 2000 habitats and species protection], Ministerstwo Środowiska [the Ministry of Environments], Warszawa: 159-170.

Kerur A.S. \& Lakshman H.C., 2009, Symbiotic response of Dianthus caryophyllus root stock to different mycorrhizal fungi, International Journal of Plant Sciences 4 (1): 166-168.

Khan A.G., 1995, Effects of various soil environmental stresses on the occurrence, distribution and effectiveness of VA mycorrhizae, Biotropia 8: 39-44.

Kondracki J., 2000, Geografia regionalna Polski [Regional geography of Poland], Wydawnictwo Naukowe PWN, Warszawa.

Kormanik P.P. \& McGraw A.C., 1982, Quantification of vesicular-arbuscular mycorrhizae in plant roots, [in:] N.C. Schenck (ed.), Methods and principles of mycorrhizal research, Amer. Phytopathol. Soc., St. Paul: 37-45.

Kowalczyk S. \& Błaszkowski J., 2005, Arbuskularne grzyby mikoryzowe gleb województwa lubuskiego [Arbuscular mycorrhizal fungi (Glomeromycota) of soils of the Lubuskie Province], Acta Agrobotanica 58 (2): 453474.

Krasicka-Korczyńska E. \& Rutkowski L., 2005, Biodiversity of Molinia meadows in Folusz near Szubin, [in:] K. Czyżewska, J. Hereźniak (eds), Biodiversity in Relation to Vegetation Zones in Europe, University of Łódź Publishing House, Łódź: 97-107.

Kulik M., 2013, Ocena szaty roślinnej wybranych łąk trzęślicowych w Poleskim Parku Narodowym i poza jego obszarem [Evaluation of vegetation of selected Molinia meadows in Polesie National Park and outside its area], Łąkarstwo w Polsce 16: 39-54.

Lekberg Y., Rosendahl S. \& Olsson P.A., 2015, The fungal perspective of arbuscular mycorrhizal colonization in 'nonmycorrhizal' plants, New Phytologist 205: 13991403.

Lingfei L., Anna Y. \& Zhiwei Z., 2005, Seasonality of arbuscular mycorrhizal symbiosis and dark septate endophytes in a grassland site in southwest China, FEMS Microbiology Ecology 54: 367-373

Matuszkiewicz J.M., 2008, Regionalizacja geobotaniczna Polski [Geobotanical regionalization in Poland], IGiPZ PAN, Warszawa.

Matuszkiewicz W., 2005, Przewodnik do oznaczania zbiorowisk roślinnych Polski [A guide for identification of plant communities in Poland], Vademecum Geobotanicum, Wydawnictwo Naukowe PWN, Warszawa.
Michalska-Hejduk D. \& Kopeć D., 2012, Zmiennowilgotne łąki trzęślicowe (Molinion), [in:] W. Mróz (ed.), Monitoring siedlisk przyrodniczych. Przewodnik metodyczny. Część III, GIOŚ, Warszawa: 40-52.

Miller R.M. \& Jastrov J.D., 1992, The role of mycorrhizal fungi in soil conservation, [in:] G. Bethlenfalvay, R. Liderman (eds), Special Publ. of the ASA, CSSA and SSSA 54: 29-44.

Mirek Z., Piękoś-Mirkowa H., Zając A. \& Zając M., 2002, Flowering plants and pteridophytes of Poland. A Checklist, W. Szafer Institute of Botany, Polish Academy of Sciences, Kraków.

Morton J.B. \& Redecker D., 2001, Two families of Glomales, Archaeosporaceae and Paraglomaceae, with to new genera Archaeospora and Paraglomus, based on concordant molecular and morphological characters, Mycologia 93: 181-195.

Nienartowicz A., Kamiński D., Kunz M., Deptuła M. \& Adamska E., 2014, Changes in the plant cover of the dune hill in Folusz near Szubin (NW Poland) between 1959 and 2013: the problem of preservation of xerothermic grasslands in the agricultural landscape, Ecological Questions 20: 23-38.

Nouri E., Breuillin-Sessoms F., Feller U. \& Reinhardt D., 2014, Phosphorus and nitrogen regulate arbuscular mycorrhizal symbiosis in Petunia hybrid, PLoS One 9 (3): e90841.

Pawłowska T.E., Błaszkowski J. \& Rühling A., 1996, The mycorrhizal status of plants colonizing a calamine spoil mound in southern Poland, Mycorrhiza 6: 499-505.

Rutkowski L., 2007, Klucz do oznaczania roślin naczyniowych Polski niżowej [Identification key for the Polish lowland vascular plants], Wydawnictwo Naukowe PWN, Warszawa.

Sawilska A.K., Jendrzejczak E. \& Kieliszewska-Rokicka B., 2010, Influence of mycorrhizal on the growth and flowering in cultivate plants of Helichrysum arenarium (L.) Moench (Asteraceae), Polish Journal of Ecology 58 (4): 627-634.

Smith S.E. \& Read D.J., 2008, Mycorrhizal Symbiosis, Academic Press, London.

St-Arnaud M., Hamel C., Vimard B., Caron M. \& Fortin J. A., 1997, Inhibition of Fusarium oxysporum f. sp. dianthi in the non-VAM species Dianthus caryophyllus by co-culture with Tagetes patula companion plants colonized by Glomus intraradices, Canadian Journal of Botany 75: 998-1005.

Trappe J.M., 1987, Phylogenetic and ecologic aspects of mycotrophy in the angiosperms from an evolutionary standpoint, [in:] G.R. Safir (ed.), Ecophysiology of VA mycorrhizal plants, CRC Press, Boca Raton, Fla: 5-25.

Trouvelot A., Kough J.L. \& Gianinazzi-Pearson V., 1986, Measure du taux de mycorrhization VA d'un système radiculaire. Recherche de méthodes d'estimation ayant 
une signification fonctionnelle, [in:] V. Gianinazzi-Pearson, S. Gianinazzi (eds), Physiological and Genetical Aspects of Mycorrhizae, INRA Press, Paris, France: 217-221.

Tyburska J., Frymark-Szymkowiak A., KulczykSkrzeszewska M. \& Kieliszewska-Rokicka B., 2013, Mycorrhizal status of forest trees grown in urban and rural environments in Poland, Ecological Questions 18: 49-57.

Wang B. \& Qiu Y. L., 2006, Phylogenetic distribution and evolution of mycorrizas in land plants, Mycorrhiza 16: 299-363.
Zubek Sz., Turnau K. \& Błaszkowski J., 2008, Arbuscular mycorrhizal of endemic and endangered plants from the Tatra Mts, Acta Societatis Botanicorum Poloniae 77(2): 149-156.

Zubek Sz., Błaszkowski J. \& Mleczko P., 2011, Arbuscular mycorrhizal and dark septate endophyte associations of medicinal plants, Acta Societatis Botanicorum Poloniae 80 (4): 285-292.

http://www2.dijon.inra.fr 